\title{
A Case of Functioning Parathyroid Carcinoma with Hypereninemic Hypertension
}

\author{
Shojiro Naomi, MD, Teruhisa Umeda, MD, Taisuke Iwaoka, MD, \\ Tatsuo Sato, MD and Kuninori UemurA*, MD
}

\begin{abstract}
A case of 49-year-old Japanese house wife with a functioning parathyroid carcinoma was reported. Because of lack of bone and renal involvements, she was classified as chemical type of primary hyperparathyroidism. Abnormally high levels of serum calcium and a small palpable tumor on the right anterior neck had suspected a functioning parathyroid carcinoma, which was proved histologically after operation. Preoperatively, she had a labile hypertension (116-190/68-126 mmHg) with high plasma renin activity (PRA; $2.3-8.4 \mathrm{ng} / \mathrm{ml} / \mathrm{h}$ ). The marked responses of PRA to furosemide and captopril were accompanied by inappropriate low response of aldosterone. After removal of the tumor, her blood pressure returned to normal with lowered PRA and normal serum calcium. These observations strongly suggested that her elevated PRA might be a main role to yield hypertension.
\end{abstract}

Key Words: Parathyroid carcinoma, Hypertension, Calcium, Parathyroid hormone, Plasma renin activity, Plasma aldosterone concentration.

A functioning parathyroid carcinoma is rare. Many authors reported that less than $5 \%$ of primary hyperparathyroidism had parathyroid carcinoma ${ }^{1,2)}$. At present, the diagnosis of parathyroid carcinoma is only possible with histopathological study of the surgical specimen.

On the other hand, Rosenthal et $\mathrm{al}^{3)}$ had pointed out that hypertension occurred in 20$50 \%$ of patients with primary hyperparathyroidism and $1 \%$ of a random group of hypertensives were found to have primary hyperparathyroidism. Our patient presented herein had labile hypertension before removal of parathyroid tumor. Postoperatively, her blood pressure quickly returned to normal levels. Since the exact cause of hypertension in hyperparathyroidism is still obscure, we investigated the interrelationships among hypercalcemia, elevated parathyroid hormone, PRA, and hypertension by means of renin stimulation test and captopril administration.

\section{CASE REPORT}

A 49-year-old Japanese house wife was admitted to the Kumamoto University Hospital on
November 12, 1981, for further evaluations of hypercalcemia.

A small palpable mass on the right lobe of thyroid gland was discovered four months ago and the biopsy specimen was diagnosed as a follicular adenoma of the thyroid. At that time, she suffered from several attacks of colicky pain in the right hypochondrium. Since two gallstones were depicted by cholecystography, the patient underwent cholecystectomy and choledochotomy on September 17, 1981. After two weeks of unevenful recovery, she begun to complain of nausea, vomiting, anorexia, polydipsia, polyuria, precordial oppression, headache and mental irritability. The serum levels of calcium was $13.9 \mathrm{mg} / \mathrm{dl}$ at that time, which increased to $16.5 \mathrm{mg} / \mathrm{dl}$ on November 2. Therefore, she was referred to our hospital and admitted in emergency.

On admission, blood pressure was $180 / 116$ $\mathrm{mmHg}$, pulse rate was 74 beats per minute with regular rhythm. Her body weight was $46 \mathrm{~kg}$, and height was $164.5 \mathrm{~cm}$. Physical examination disclosed a thumb-head-sized tumor on the middle portion of the thyroid lobe. Blood chemistry gave

\footnotetext{
From the Third Department of Internal Medicine, and *the First Department of Surgery, Kumamoto University School of Medicine, Honjo 1-1-1, Kumamoto 860, Japan.

Received for publication September 27, 1982.

Reprint request to: Shojiro Naomi, MD, The Third Department of Internal Medicine, Kumamoto University School of Medicine, Honjo 1-1-1, Kumamoto 860, Japan.
} 
the following values: serum calcium, $13.7 \mathrm{mg} / \mathrm{dl}$; serum inorganic phosphate, $2.2 \mathrm{mg} / \mathrm{dl}$; serum sodium, $140 \mathrm{mEq} / 1$; serum potassium, $3.9 \mathrm{mEq} / \mathrm{l}$; and serum alkaline phosphatase, $136 \mathrm{u} / \mathrm{l}$. Urine volume was $2300 \mathrm{ml} /$ day and urinary outputs of calcium and phosphate were $304 \mathrm{mg} /$ day and $360 \mathrm{mg} /$ day, respectively. PSP excretion rate in first 15 minutes was $17.5 \%$ and creatinine clearance was $45.6 \mathrm{ml} / \mathrm{min}$. Plain X-ray examination on the chest, abdomen, skull and extremities showed no abnormal findings. The blood gas analysis revealed $\mathrm{pH} 7.4$ and bicarbonate $24 \mathrm{mmol} / \mathrm{l}$. Percent of tubular reabsorption of phosphate (\%TRP) was $66.8 \%$ and nephrogenous cyclic AMP was $4.1 \mathrm{nmol} / 100 \mathrm{ml}$ of glomerular filtration rate. Plasma levels of parathyroid hormone were 2.05$3.49 \mathrm{ng} / \mathrm{ml}$ (normal range; $0.2-1.0 \mathrm{ng} / \mathrm{ml}$ ). Scinti. graphy of the thyroid gland revealed that ${ }^{201} \mathrm{Tl}$

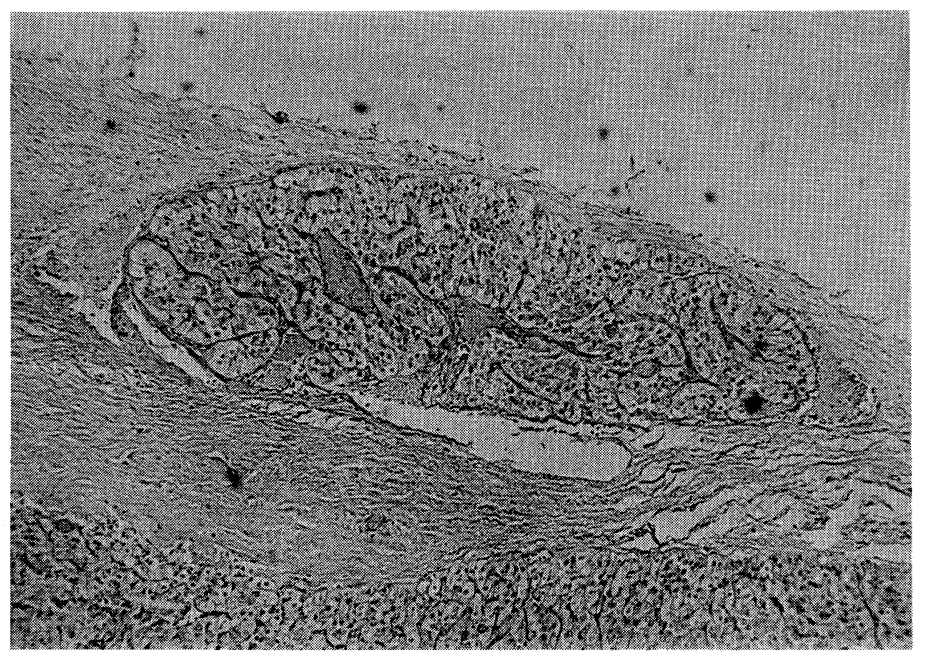

Fig. 1. Section of parathyroid carcinoma was shown, demonstrating the tumor cell invasion into a capsular vessel. (hematoxylin-eosin, original magnification $\times 400$ )

Table 1. Clinical features before and after surgical removal of parathyroid carcinoma

\begin{tabular}{llll}
\hline & & before & after \\
\hline Serum calcium & $(\mathrm{mg} / \mathrm{dl})$ & $12.4-16.5$ & $8.8-9.0$ \\
Serum phosphate & $(\mathrm{mg} / \mathrm{dl})$ & $1.3-2.4$ & 3.1 \\
Urine calcium & $(\mathrm{mg} / \mathrm{day})$ & $303-584$ & $203-272$ \\
Urine phosphate & $(\mathrm{mg} / \mathrm{day})$ & $270-410$ & $240-320$ \\
Serum PTH & $(\mathrm{ng} / \mathrm{ml})$ & $2.05-3.49$ & $0-0.33$ \\
Urine volume & $(\mathrm{ml} / \mathrm{day})$ & $2300-5000$ & $1400-3900$ \\
Creatinine clearance & $(\mathrm{ml} / \mathrm{min})$ & 45.6 & 69.0 \\
& $(\mathrm{~kg})$ & 45 & 52 \\
Body weight & $(\mathrm{mmHg})$ & $122 / 82-198 / 132$ & $102 / 56-134 / 82$ \\
Blood pressure & $\left(\times 10^{4} / \mathrm{mm}^{3}\right)$ & $315-419$ & $233-256$ \\
Peripheral RBC & $(\%)$ & $30.1-40.0$ & $21.4-23.9$ \\
Hematocrit & & &
\end{tabular}


was accumulated to the palpable neck mass, while ${ }^{99 \mathrm{~m}}$ Tc was not. Echography of the neck tumor gave the solid echo pattern. From the results, the patient was initially diagnosed as chemical type of primary hyperparathyroidism due to parathyroid adenoma.

The neck surgery was performed on December 21,1981 , under the general anesthesia with $\mathrm{N}_{2} \mathrm{O}$ gas inhalation. An oblique incision on the right carotid triangle revealed a sparrow-egg-sized mass behind the right lobe of thyroid gland. En block excision of the tumor with the whole right thyroid gland and modified radical neck dissection of the same side were performed because of the possibility of malignancy in frozen section of the lesion. There was no apparent enlargement of lymphonodes and residual parathyroid glands.

The tumor was well encapsulated, elastic soft and reddish-brown-colored, $2.5 \times 2.5 \times 2.0 \mathrm{~cm}$ in size and $7.4 \mathrm{~g}$ in weight. The histopathological studies revealed parathyroid carcinoma with capsular and vascular invasion (Fig. 1).

After surgery the symptoms of nausea, vomiting, anorexia, polyuria, polidipsia and general malaise were diminished rapidly. Elevated levels of serum calcium and PTH and urinary output of calcium returned to normal range. Preoperative urine volumes of 2300 to $5000 \mathrm{ml} /$ day were decreased to 1400 to $3900 \mathrm{ml} /$ day with lowering hematocrit after surgery. Creatinine clearance was increased from $45.6 \mathrm{mg} / \mathrm{min}$ to $69.0 \mathrm{ml} / \mathrm{min}$ as shown in Table 1. Postoperatively, the labile hypertension observed before surgery was normalized and basal PRA remarkably decreased from 2.5 to $0.1 \mathrm{ng} / \mathrm{ml} / \mathrm{h}$. The responses of PRA to stimulations with furosemide and captopril were also attenuated in Table 2 and 3.

\section{DISCUSSION}

Parathyroid carcinoma is a rare cause of primary hyperparathyroidism. It is a relatively slowgrowing cancer and is curable by adequate operation. Local recurrences as well as distant metastases also may be amenable to surgical excision. Our patient reported herein manifested both hypercalcemia over $16 \mathrm{mg} / \mathrm{dl}$ and a palpable neck mass. Holmes et $\mathrm{al}^{4)}$ described that coexistence of hypercalcemia more than $14 \mathrm{mg} / \mathrm{dl}$ with a palpable neck mass might be a clinical evidence for functioning parathyroid carcinoma. It has also been reported that bone involvement and renal stone were more common in parathyroid carci-

Table 2. Renin stimulation test* before and after surgical removal of parathyroid carcinoma

\begin{tabular}{lcccc}
\hline & Plasma & $\begin{array}{c}\text { renin activity(PRA) } \\
(\mathrm{ng} / \mathrm{ml} / \mathrm{h})\end{array}$ & Plasma & $\begin{array}{l}\text { aldosterone concentration( PAC) } \\
(\mathrm{ng} / 100 \mathrm{~m} 1)\end{array}$ \\
\hline & before & after & before & after \\
0 & 2.5 & 0.1 & 3.3 & 1.9 \\
$1 \mathrm{hr}$ & 21.4 & 0.4 & 6.0 & 17.2 \\
$2 \mathrm{hr}$ & 15.8 & 0.7 & 8.4 & 24.8 \\
\hline
\end{tabular}

*Renin release was stimulated by furosemide $1 \mathrm{mg} / \mathrm{kg}$ i.v. at time zero and standing for two hours.

Table 3. Captopril administration test* before and after surgical removal of parathyroid carcinoma

\begin{tabular}{|c|c|c|c|c|c|c|c|c|}
\hline & \multicolumn{2}{|c|}{$\begin{array}{c}\text { PRA } \\
(\mathrm{ng} / \mathrm{ml} / \mathrm{h})\end{array}$} & \multicolumn{2}{|c|}{$\begin{array}{c}\text { PAC } \\
(\mathrm{ng} / 100 \mathrm{ml})\end{array}$} & \multicolumn{2}{|c|}{$\begin{array}{l}\text { Mean blood pressure } \\
(\mathrm{mmHg})\end{array}$} & \multicolumn{2}{|c|}{$\begin{array}{l}\text { Pulse rate } \\
\text { (beats/min) }\end{array}$} \\
\hline & before & after & before & after & before & after & before & after \\
\hline 0 & 3.7 & 0.1 & 2.5 & 4.5 & 100.0 & 89.0 & 53 & 48 \\
\hline $1 \mathrm{hr}$ & 16.0 & 0.1 & 1.5 & 2.4 & 84.0 & 88.7 & 52 & 48 \\
\hline $2 \mathrm{hr}$ & 21.7 & 0.1 & 1.6 & 2.5 & 88.0 & 86.7 & 56 & 48 \\
\hline
\end{tabular}

*Captopril 50mg was administrated orally. 
noma than in benign parathyroid hyperpalsia and adenoma. However, our case did not show any manifestations of bone and renal involvement and thus, she was initially classified as a chemical type. At present, there are no definitive indicators for malignancy of parathyroid tumor in both laboratory and physical findings except for only histological study of surgical specimens. Examination of a frozen section of the lesion is essential. However, differentiation between benign and malignant nodule is frequently difficult. Thus, if the diagnosis is unsure, unilateral lobectomy of the thyroid gland with modified neck dissection should be done.

It is known that arterial hypertension concurs in 20 to $50 \%$ of patients with primary hyperparathyroidism $^{3}$. The exact mechanism of hypertension concomitant with the disease is still unknown. Brinton et $\mathrm{al}^{5)}$ reported 4 hypertensive cases of primary hyperparathyroidism, of which PRA were elevated initially but both hypertension and elevated PRA had returned to normal after surgical removal of parathyroid adenoma. Recent studies have demonstrated that captopril, an angiotensin converting enzyme inhibitor, was quite effective for the hypertension associated with primary hyperparathyroidism ${ }^{6}$. . Zawada et al $^{7)}$ reported no significant effect of saralasin, an angiotensin II analogue, on both PRA and blood pressure in hypertensive patients with primary hyperparathyroidism.

In our case, both basal and stimulated PRA levels before surgery were remarkably high and returned to low levels after surgery. These observations supported the hypothesis that the hypertension in this case observed before surgery might be due to elevated angiotensin II. Although the mechanisms of elevated PRA were obscure, following explanations might be acceptable. Firstly, elevated blood pressure probably reflected stimulation of renin release by hypercalcemia. It was shown that acute loading of calcium gluconate had not increased PRA in $\operatorname{man}^{8,9)}$, but Sowers et al ${ }^{10}$ ) reported the positive correlation between serum calcium levels and PRA in the hypercalcemic Fisher rats. Secondly, elevated PTH might be related to the increment of PRA. McCredie et al ${ }^{11)}$ demonstrated a rapid increase of PRA in dogs after intravenous administration of crude parathyroid extract, but they and Epstein et $\mathrm{al}^{8)}$ failed to show any such effect with pure parathyroid hormone. Therefore, it seemed unlikely that PTH itself had direct action on renin release from juxtaglomerular cell, though PTH levels were elevated during preoperative period in our case. Thirdly, dehydration resulted from polyuria and anorexia which deteriorated general condition of the patient with primary hyperparathyroidism might contribute to high PRA. In fact, the hematocrits in our case, 30.1 to $40.0 \%$ before surgery, lowered to 21.4 to $23.9 \%$ after surgery. The volume depletion could be a potent stimulant for renin release. The third mechanism was most probable, though plasma volume was not determined in our case.

The elevated angiotensin II generated by increased plasma renin might play a main role in the hypertension observed in our case. The possibility could be supported by the marked decrease of blood pressure after captopril administration. Postoperatively, captopril gave only minimal changes in blood pressure. Moreover, it seemed unlikely that the secondary hyperaldosteronism was the cause of hypertension in our case because of the hypereninemic hypoaldosteronism was found before the removal of the tumor. Such phenomena had been shown in hypercalcemic Fisher rats with neoplasia ${ }^{10)}$, but the underlying mechanism of blunted secretion of aldosterone remained obscure. Another mechanism of the hypertension in hypercalcemia might be the enhanced vascular reactivity to angiotensin II. Sowers et al ${ }^{10)}$ clearly demonstrated the elevated PRA and the increased sensitivity of angiotensin II receptor by cumulative infusion of angiotensin II in hypercalcemic Fisher rats. In addition, the mechanisms of hypertension had been discussed with a direct vasoconstrictive action of calcium ${ }^{9)}$ or increased activity of the sympathetic nervous system in hypercalcemia ${ }^{12)}$. As the mechanism of hypertension in primary hyperparathyroidism is complexed as described above, further investigations are desirable.

In summary, the elevated levels of circulating angiotensin II due to increased renin release may be essential in the hypertension observed in our case of functioning parathyroid carcinoma. 


\section{REFERENCES}

1) Schantz A, Castleman B: Parathyroid carcinoma: A study of 70 cases. Cancer 31: 600, 1973.

2) Jarman WT, Myers RT, Marshall RB: Carcinoma of the parathyroid. Arch surg 113: 123, 1978.

3) Rosenthal FD, Roy S: Hypertension and hyperparathyroidism. Br Med J 4: 396, 1972.

4) Holmes EC, Morton DL, Ketcham AS: Parathyroid carcinoma: A collective review. Ann Surg 169: 631, 1969.

5) Brinton GS, Jubiz W, Langerquist LD: Hypertension in primary hyperparathyroidism: The role of the renin-angiotensin system. J Clin Endocrinol Metab 41: 1025, 1975.

6) Waeber B, Brunner HR, Bruckhardt P, et al: Hypertension associated with hypercalcemia: Captopril and verapamil. Arch Intern Med 142: 143, 1982.

7) Zawada ET, Brickman AS, Maxwell MH, et al: Hypertension associated with hyperparathyroidism is not responsive to angiotensin blockade. J Clin Endocrinol Metab 50: 912, 1980.
8) Epstein S, Sagel J, Brodovcky H, et al: Absence of an acute effect of calcium or parathyroid hormone administration on plasma renin activity in man. Clin Sci Mol Med 50: 79, 1976.

9) Marone C, Beretta-Piccoli C, Weidmann P: Acute hypercalcemic hypertension in man: Role of hemodynamics, catecholamines, and renin. Kidney Int 20: $92,1980$.

10) Sowers JR, Sollars E, Nyby MD, et al: Hypereninemic hypoaldosteronism in association with neoplasia induced hypercalcemia in the Fisher rat. Metabolism 30: 987, 1981.

11) McCredie DA, Powell HR, Rotenberg E: Effect of parathyroid extract on renin release in the dog. Clin Sci Mol Med 48: 461, 1975.

12) Vlachakis ND, Frederics R, Velasguez $M$, et al: Sympathetic system function and vascular reactivity in hypercalcemic patients. Hypertension 4: 452, 1982. 